\title{
Understanding Anionic Chugaev Elimination in Pericyclic Tetracene Formation
}

Laurence Burroughs, John Ritchie, Simon Woodward*

${ }^{a}$ School of Chemistry, University of Nottingham, University Park, Nottingham NG7 2RD (United Kingdom)

Article history:

Received

Received in revised form

Accepted

Available online

Key words: 3,3-Sigmatropic rearrangement, elimination, aromatisation, DFT Study, Chugaev, thiotetracene

Abstract: The reaction pathway for the formation of tetracenes from the diols $1,2-\mathrm{C}_{6} \mathrm{H}_{4}(\mathrm{CHOHC} \equiv \mathrm{CAr})_{2}$, LiHDMS, $\mathrm{CS}_{2}$ and Mel has been modelled by computational methods at the CBS-QB3 level of theory. Comparison of $\mathrm{PhCHOC}(=\mathrm{S}) \mathrm{YCCPh}\left(\mathrm{Y}=\mathrm{S}^{-}\right.$or $\left.\mathrm{SMe}\right)$ indicates a slight kinetic advantage for the anionic system towards [3,3]-sigmatropic rearrangement [ $\mathrm{E}_{\text {act }}\left(\mathrm{calc}\right.$.) $19.7 \mathrm{vs} 21.8 \mathrm{kcal} \mathrm{mol}^{-1}$ ]. Using anthracene-based models, $10-\{\mathrm{SC}(=\mathrm{O}) \mathrm{Y}\}-4 \mathrm{a}, 10$-dihydroanthracene $\left(\mathrm{Y}=\mathrm{S}^{-}\right.$or $\left.\mathrm{SMe}\right)$, allows direct comparison of both syn and anti-manifolds in the neutral vs. anionic Chugaev elimination. Syn elimination of $[\mathrm{HSC}(=\mathrm{O}) \mathrm{S}]^{-}$is distinctly favoured $\left[\mathrm{E}_{\text {act }}\right.$ (calc.) $11.4 \mathrm{kcal} \mathrm{mol}^{-1}$ ] vs. syn elimination of neutral methylated $\mathrm{HSC}(=0) \mathrm{SMe}\left[\mathrm{E}_{\text {act }}(\mathrm{calc}\right.$.) 27.5 $\mathrm{kcal} \mathrm{mol}^{-1}$ ]. The smaller barrier to syn elimination of the anionic leaving group is in accord with the low temperature conditions required for this Chugaev reaction $\left(60^{\circ} \mathrm{C}\right)$ and suggests a general advantage in carrying out Chugaev eliminations in anionic manifolds.

\section{Introduction}

Tetracene and its substituted analogues are attractive fragments for the development of both photoelectric $^{1}$ and thermoelectric devices. ${ }^{2}$ Unlike lower acene homologs, which are widely available, tetracenes must be synthesized. While many synthetic strategies have been devised ${ }^{3}$ these can be step intensive and the consolidated yields are often further compromised by isolation and scale-up issues associated with poor acene solubility. One potential method for overcoming these difficulties is through the use of cascade processes whereby the tetracene target is attained by a series of pericyclic reactions. Examples of such approaches can be found in the work of $\operatorname{Lin}^{4}$ and Liu. ${ }^{5}$

In 2015 we described the one-pot transformation of diols $\mathbf{1}$ to the thiolated tetracenes $\mathbf{2}$ via a cascade based on xanthate formation (Scheme 1). ${ }^{6}$ The reactivity of this system was in accord with the initial step in the cascade being triggered from the anionic intermediate $\mathbf{A}$, as the isolable di-SMe analogue of $\mathbf{A}$ (the xanthate attained by Mel dialkylation), was inert toward rearrangement to $\mathbf{2}$ at high temperatures (up to $250{ }^{\circ} \mathrm{C}$ ). Both the $[3,3]$ sigmatropic rearrangements resulting from $\mathbf{A}$ and the subsequent $6 \pi$ electrocyclic rearrangements needed to access the cyclization precursor B have stereospecific requirements; anti-1 leading to syn-B and conversely syn-1 providing anti-B as a consequence of Woodward-Hoffman selectivities. The potential final yields of the tetracenes 2 thus depend on: (i) the syn:anti ratio in the initial sample of $\mathbf{1}$ and (ii) the relative efficacy of elimination of the $[\mathrm{HSC}(=\mathrm{O}) \mathrm{S}]^{-}$from syn- and anti-B. The 
electronic properties of substituents $R^{1}$ and $R^{2}$ clearly moderate the requirements ( $\left.i-i i\right)$ - For example, compare the quantitative yield realized for $\mathbf{2} \mathbf{b}$ vs. those for $\mathbf{2} \mathbf{d}$ and $\mathbf{2} \mathbf{e}$. Finally, the situation is further complicated by potential additional access to $\mathbf{2}$ via elimination of neutral leaving groups from anti-B where $\mathrm{Y}$ is $[\mathrm{HSC}(=\mathrm{O}) \mathrm{SMe}]$.<smiles>[R]c1cc(C#CC(O)c2ccccc2C(O)C#Cc2cc([R])c([R])c([R])c2)cc([R])c1[R]</smiles><smiles>[R]c1cc(-c2c3cc4ccccc4cc3c(SC(=O)S)c3cc([R])c([R])c([R])c23)cc([R])c1[R]</smiles>

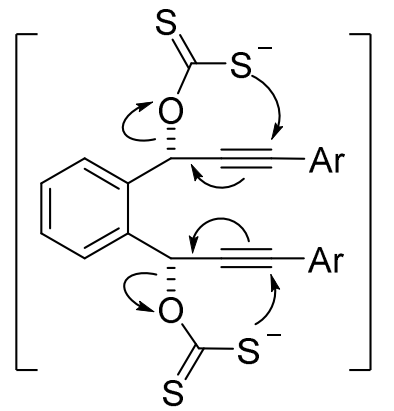<smiles>[R]C1=CC2=C(SC(=O)[S-])c3cc4ccccc4cc3C([Y])([Y])[C@]2([R])C([R])=C([R])C1</smiles>

\begin{tabular}{c|llc} 
2a-f & $\mathrm{R}^{1}$ & $\mathrm{R}^{2}$ & Yield/\% \\
\hline $\mathrm{a}$ & $\mathrm{H}$ & $\mathrm{H}$ & $60-85$ \\
$\mathrm{~b}$ & $\mathrm{OMe}$ & $\mathrm{H}$ & $>99$ \\
$\mathrm{c}$ & $\mathrm{CF}_{3}$ & $\mathrm{H}$ & 56 \\
$\mathrm{~d}$ & $\mathrm{OMe}$ & $\mathrm{OMe}$ & 47 \\
$\mathrm{e}$ & $\mathrm{H}$ & $\mathrm{OMe}$ & 38 \\
$\mathrm{f}$ & $\mathrm{H}$ & $\mathrm{CF}_{3}$ & 43 \\
$\mathrm{~g}$ & $\mathrm{H}$ & $t \mathrm{Bu}$ & 22 \\
$\mathrm{~h}$ & $\mathrm{H}$ & $\mathrm{Me}$ & 26
\end{tabular}

Scheme 1. Synthesis of substituted tetracenes $\mathbf{2}$ from diols $\mathbf{1}$ and the potential key steps $\ln$ the cascade: $[3,3]$ sigmatropic rearrangement $(\mathbf{A})$ and Chugaev elimination of $[\mathrm{HSC}(=\mathrm{O}) \mathrm{S}]^{-}(\mathbf{B})$.

\section{Results and Discussion}

Previously we have found DFT computational methods useful tools in determining thiocarbonyl reaction pathways in the Newman-Kwart rearrangement. ${ }^{7}$ We chose to model the behaviour of $\mathbf{A}$ and $\mathbf{B}$ with in silico studies of truncated model systems $3-4 \mathrm{~A}$ and $7-8 \mathrm{~B}$ respectively (Scheme 2 ).

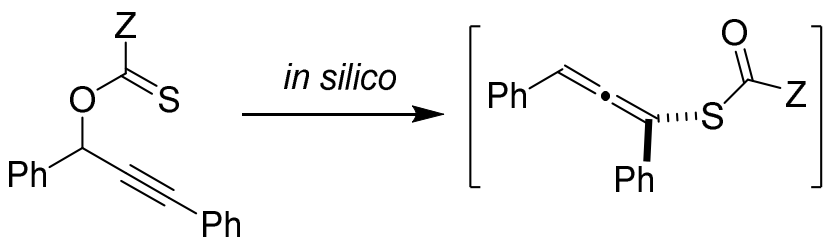
3A $Z=S^{-}$
5A $Z=S^{-}$
4A $Z=S M e$
6A $Z=S M e$<smiles>[Z]C(=O)SC1c2ccccc2C=C2C=CC=CC21C</smiles>

7B $Z=S^{-}$

8B $Z=S M e$

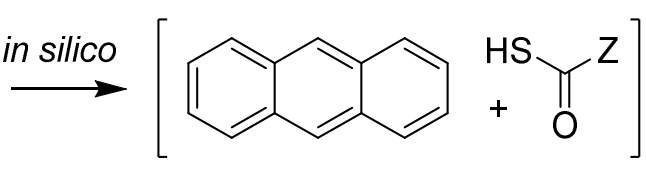

9B $Z=S^{-}$

10B $Z=S M e$ 
Scheme 2. Computational models used for the key $[3,3]$ sigmatropic rearrangements and aromatizing elimination in the formation of the tetracenes of Scheme 1.

Models 3-4A (propargylic xanthate [3,3]-sigmatropic rearrangement) and 7-8B (anthracene formation) were selected as they were small enough to be acceptable with higher level CBS-QB3 calculations, yet represent valid truncations of the real molecules. In fact the real world behaviour of 3-4A mixtures has already been studied by us and formation of the allene $6 \mathrm{~A}$ confirmed. ${ }^{6}$ To attain initial geometries on starting materials, products and transition states simple B3LYP/6-31+G(d,p) ${ }^{8}$ DFT studies were carried out. However, because of known issues regarding energy error bounds ${ }^{9}$ on B3LYP calculated energies, the geometries were further optimized and Gibbs Free Energies calculated using the CBS-QB3 ${ }^{10}$ composite method. The calculated energy barriers are given in Table 1. It is clear that in the anionic manifold a syn elimination of $[\mathrm{HSC}(=\mathrm{O}) \mathrm{S}]^{-}$is highly favoured over the equivalent syn elimination of $\mathrm{HSC}(=0) \mathrm{SMe}$; the $\delta \mathrm{E}_{\text {act }}$ (calc) of $16.1 \mathrm{kcal} \mathrm{mol}^{-1}$ corresponds to an effective rate advantage of $>10^{10}$ at $60{ }^{\circ} \mathrm{C}^{11}$ The $[3,3]$ sigmatropic rearrangements have very similar $\delta \mathrm{E}_{\text {act }}(\mathrm{calc})$ energies of $\sim 20 \mathrm{kcal} \mathrm{mol}^{-1}$, and these calculations suggest that the reverse step back to $3 \mathbf{A} / 4 \mathrm{~A}$ is highly endoergic with $\delta \mathrm{E}_{\text {act }}(\mathrm{calc})$ energies of $\sim 40 \mathrm{kcal} \mathrm{mol}^{-1}$.

Table 1. Calculated energy barriers (CBS-QB3) for [3,3]-sigmatropic rearrangement and eliminations.

\begin{tabular}{|c|c|c|c|c|}
\hline Starting point & Process & Endpoint & $\mathrm{E}_{\mathrm{act}}(\mathrm{calc})\left(\mathrm{kcal} \mathrm{mol}^{-1}\right)$ & $\Delta \mathrm{G}_{\mathrm{f}}{ }^{\circ}$ (calc) $\left(\mathrm{kcal} \mathrm{mol}^{-1}\right)$ \\
\hline $3 A$ & {$[3,3]$-sigmatropic rear. } & $5 A$ & +19.7 & -20.7 \\
\hline $4 A$ & {$[3,3]$-sigmatropic rear. } & $6 A$ & +21.8 & -19.9 \\
\hline 7B & syn-elimination & $9 B$ & +11.4 & -27.3 \\
\hline 8B & syn-elimination & 10B & +27.5 & -25.7 \\
\hline
\end{tabular}

This analysis is in accord with $\mathbf{1 b}$ being the optimal substrate in our original work. ${ }^{6}$ This compound is isolated with a high anti:syn ratio (favouring the formation of syn-B intermediates prior to elimination). It is also possible that the proximal oxygen (at $\mathrm{R}^{1}$ ) also helps order the transition for the elimination via coordination of the lithium cation associated with the eliminating group. However, disentangling the specific electronic effects of all the substituents was not practical computationally. Indeed subtle changes can have significant effects in this system. For example, in our original system we had noted the distinctly poorer performance of the para-substituted phenyl derivatives (1e-g) compared to the parent 1a. The difference in the anti/syn ratios of these compounds ( 1:1 for 1e-g vs. 1.6:1 for 1a) does not fully account for this. As the steric profile of para units in 1e-g were either large (the $\mathrm{OMe}, \mathrm{CF}_{3}$ and $t \mathrm{Bu}$ volumes are 30.4, 39.8 and $73.5 \AA^{3}$ respectively $\left.{ }^{12}\right)$ or they had strong electronic effect $\left(\sigma-0.27,+0.42,-0.10\right.$ respectively $\left.{ }^{13}\right)$ we also prepared $\mathbf{2 h}$ bearing a methyl group with modest average $\left(21.6 \AA^{3}, \sigma-0.17\right)$ steric and electronic parameters for $\mathbf{1 h}$ (and with anti/syn ratio 1.9:1.0). Unexpectedly, the isolated yield of $\mathbf{2} \mathrm{h}$ was also low (26\%) compared to parent $2 \mathrm{a}(60-85 \%)$ indicating the difficulties in fully understanding the substituent effects. We have also considered the possibility of eliminations from anti-B type structures (Scheme 1). In the highest yielding substrates (e.g. 1b with anti/syn ratio of 1.9:1) even the residual syn diastereomer must be converted to the final tetracene by an anti-B type intermediate. However, despite an extensive computational search no reaction pathway for spontaneous anti elimination of either $[\mathrm{HSC}(=\mathrm{O}) \mathrm{S}]^{-}$or $\mathrm{HSC}(=0)$ SMe from the anti-analogues of $7 \mathrm{~B}$ and $\mathbf{8 B}$ could be found. Simple $\mathrm{E} 2$ model elimination from anti7B using hydroxide as a model for any alkoxide base present in the reaction mixture, provided a ca. $13 \mathrm{kcal}$ $\mathrm{mol}^{-1}$ barrier to elimination at the $B 3 \mathrm{LYP} / 6-31+G(d, p)$ level of theory but no convergence was attained with 
higher level CBS-QB3 (Supporting Information). A similar situation was found for the hydroxide induced E2 elimination from anti-8B except in this case a barrier of $\sim 10 \mathrm{kcal} \mathrm{mol}^{-1}$ was attained. It should be noted that these vacuum calculations poorly describe base-induced E2 elimination, since the approach of hydroxide will lead to a lowering of energy due to charge-induced dipole interactions. These would be cancelled out in solution by the loss of similar anion-solvent interactions. While care must be taken in interpreting these B3LYP results they do suggest anti elimination offers a viable alternative for anti B-type diastereomers that are predicted to be otherwise unreactive.

Finally, we have investigated the vertical excitation energies of the first singlet $(S)$ and triplet $(T)$ excited states of the tetracenes 2 by time-dependant DFT methods. Time-dependent DFT methods can provide estimates of the excitation energy from the electronic ground state to the first (or higher) excited state, including singlet and sometimes triplet excited states for closed-shell singlet ground states. It does this by simulating vertical transposition of one electron from an occupied orbital of the ground state to an unoccupied orbital of the ground state. Provided the excitation is dominated by HOMO-to-LUMO character then estimates of the energies of unoccupied singlet (S) and triplet $(\mathrm{T})$ excited states of the system can be attained. These values are of major interest in the design of efficient singlet fission solar cells; discovered in $1965,{ }^{14}$ this particular photovoltaic system is attractive as formally one photon can provide two excitons. In order to maximize the likelihood of singlet fission occurring it is desirable to have the ratio of the excitation energies of the triplet and singlet state $(S / T$, Table 2$)$ similar to that of the parent tetracene $\left(\mathrm{C}_{18} \mathrm{H}_{12}\right)$, which is common to most of the devices that have been prepared thus far. ${ }^{1}$ The energies calculated for both tetracene and the substituted analogues $\mathbf{2 a - h}$ are presented in Table 2 . These values suggest that certain derivatives $(\mathbf{2 a}, \mathbf{2 g})$ are attractive for further investigation in singlet fission OPV devices.

Table 2. Calculated singlet $(\mathrm{S})$ and triplet $(T)$ in substituted $\mathbf{2 a - h}$ and parent tetracene $\left(\mathrm{C}_{18} \mathrm{H}_{12}\right)$.

\begin{tabular}{cccccccc}
\hline Compound & S state $(\mathrm{eV})$ & T state $(\mathrm{eV})$ & $\mathrm{S} / \mathrm{T}$ & Compound & S state $(\mathrm{eV})$ & T state $(\mathrm{eV})$ & $\mathrm{S} / \mathrm{T}$ \\
\hline tetracene & 2.748 & 0.842 & 3.26 & $\mathbf{2 a}$ & 2.648 & 0.935 & 2.83 \\
$\mathbf{2 b}$ & 2.627 & 1.530 & 1.72 & $\mathbf{2 c}$ & 2.936 & 1.530 & 1.92 \\
$\mathbf{2 d}$ & 2.580 & 1.008 & 2.56 & $\mathbf{2 e}$ & 2.663 & 1.020 & 2.61 \\
$\mathbf{2 f}$ & 2.744 & 1.114 & 2.46 & $\mathbf{2 g}$ & 2.725 & 0.905 & 3.01 \\
$\mathbf{2 h}$ & 2.607 & 0.949 & 2.75 & $\mathbf{1 1 ^ { \mathrm { a } }}$ & 3.086 & 1.551 & 1.99 \\
\hline
\end{tabular}

${ }^{\text {a }}$ Compound $\mathbf{1 1}$ is:

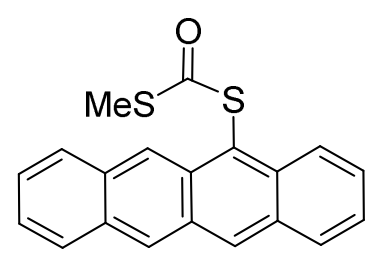

11

\section{Conclusions}

DFT (CBS-QB3) studies are in accord with the conversion of anti diols 1 upon treatment with LiHDMS, $\mathrm{CS}_{2}$ and Mel to intermediates (B) arising from cascading [3,3]-sigmatropic rearrangements and $6 \pi$ electrocyclizations. Conversion of intermediate $\mathbf{B}$ to the final tetracene $\mathbf{2}$ is favoured when syn anionic 
Chugaev elimination is realized [ $E_{\text {act }}($ calc $) 11.4 \mathrm{kcal} \mathrm{mol}^{-1}$ ]. Elimination of the neutral xanthate is of prohibitive energy cost $\left[\mathrm{E}_{\text {act }}(\mathrm{calc}) 27.5 \mathrm{kcal} \mathrm{mol}^{-1}\right]$. In the absence of syn elimination processes anti elimination is only viable in the presence of an external base. The barrier to this was estimated to be ca. 10$14 \mathrm{kcal} \mathrm{mol}^{-1}$ but was limited by the level of theory that could be employed.

\section{Experimental}

The instrumentation, reagents and general preparations of diols $\mathbf{1}$ and tetracenes $\mathbf{2}$ have been previously described. ${ }^{6}$ Compound $\mathbf{1 h}$ is known. ${ }^{5}$ Preparative details of new compound $\mathbf{2 h}$ are given below. All calculations were carried out using Gaussian 09, Revision D. $01^{15}$ with default settings. Initial structure searches for mapping of the reaction coordinate were run at the $B 3 L Y P / 6-31+G(d, p)^{8}$ level of theory, and the resulting structures further optimized using $\mathrm{CBS}-\mathrm{QBB} 3^{10}$ with 'tight' convergence and 'UltraFine' integration grid keywords specified. Transition-state structures were all characterized by a single imaginary vibrational frequency. Approximations for the HOMO eigenvalues of all tetracenes were calculated at the CAM-B3LYP/6-31G $(d, p)^{16}$ level of theory. Values for the HOMO-LUMO gaps and energies of the first singlet and triplet excited states of all tetracenes were calculated using TD-SCF CAM-B3LYP/6-31G $(d, p)^{16}$ with the tda (Tamm-Dancoff Approximation) ${ }^{17}$ keyword, taking the excitation energy of the first singlet excited state as the HOMO-LUMO gap. ${ }^{18}$ GaussView $5^{19}$ was used to generate all the 3D-molecular structure figures. Full details of the optimized geometries are given in the Supporting Information.

\subsection{2-Methyl-12-(4'-methylphenyl)-5-(((methylthio)carbonyl)thio)-tetracene (2h)}

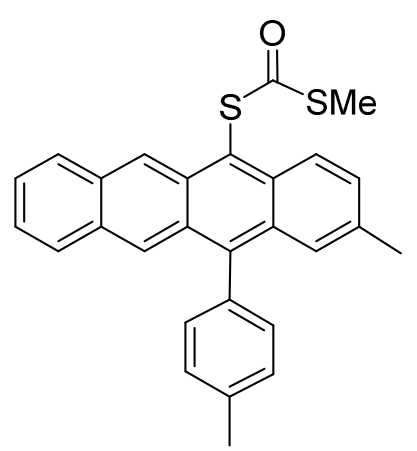

From diol 1 h ( $80 \mathrm{mg}, 0.18 \mathrm{mmol}$ ), LiHDMS ( $0.35 \mathrm{~mL}, 1.0 \mathrm{M}$ in THF, $0.35 \mathrm{mmol}$ ), $\mathrm{CS}_{2}(32 \mu \mathrm{L}, 40.6 \mathrm{mg}, 0.53 \mathrm{mmol})$ and iodomethane ( $\left.88 \mu \mathrm{L}, 202 \mathrm{mg}, 1.42 \mathrm{mmol}\right)$ to yield $2 \mathrm{~h}$ as an orange solid, $20.5 \mathrm{mg}, 26 \%$ that could be recrystallized by liquid layering (pentane:ether). $\mathrm{R}_{f} 0.71\left(7: 3\right.$ pentane:ether). m.p. $136-138^{\circ} \mathrm{C}, \mathrm{IR}$ $\left(\mathrm{CHCl}_{3}\right): v_{\max } / \mathrm{cm}^{-1} 3690,3051,3009,2958,2927,2857,2735,1720,1638,1604$, $1536,1514,1494,1465,1420,1380,1341,1312,1284,1262,1243,11182$, $1124,1107,1038,1022,972,907,881,853,823,{ }^{1} \mathrm{H}$ NMR $\left(500.1 \mathrm{MHz}, \mathrm{CDCl}_{3}\right): \delta$ $9.34(\mathrm{~s}, 1 \mathrm{H}), 8.63(\mathrm{~d}, J=9.1 \mathrm{~Hz}, 1 \mathrm{H}), 8.31(\mathrm{~s}, 1 \mathrm{H}), 8.07(\mathrm{~d}, J=8.6 \mathrm{~Hz}, 1 \mathrm{H}), 7.81(\mathrm{~d}$, $J=8.6 \mathrm{~Hz}, 1 \mathrm{H}), 7.49-7.44(\mathrm{~m}, 2 \mathrm{H}), 7.42(\mathrm{ddd}, J=8.6,6.4,0.9 \mathrm{~Hz}, 1 \mathrm{H}, \mathrm{ArH}), 7.40$ $(\mathrm{dd}, J=9.1,1.6 \mathrm{~Hz}, 2 \mathrm{H}), 7.37-7.32(\mathrm{ddd}, J=8.6,6.4,0.9 \mathrm{~Hz}, 1 \mathrm{H}, \mathrm{ArH}), 2.60\left(\mathrm{~s}, \mathrm{CH}_{3}\right), 2.41\left(\mathrm{~s}, 3 \mathrm{H}, \mathrm{CH}_{3}\right), 2.29$ $\left(\mathrm{s}, 3 \mathrm{H}, \mathrm{SCH}_{3}\right)$, remaining signals could not be assigned due to extensive overlap of signals in the ${ }^{1} \mathrm{H}$ NMR, but where observed in COSY spectrum. ${ }^{13} \mathrm{C} \mathrm{NMR}\left(125.8 \mathrm{MHz}, \mathrm{CDCl}_{3}\right): \delta 190.8$ (C), 141.7 (C), 137.7 (C), 135.7 (C), 134.7 (C), 134.4 (C), 132.2 (C), 132.1 (C), 131.3 (C), $131.2(\mathrm{CH}), 130.6(\mathrm{CH}), 130.5$ (C), 130.1 (C), $129.4(\mathrm{CH})$, $128.7(\mathrm{CH}), 128.6(\mathrm{CH}), 127.1(\mathrm{CH}), 126.2(\mathrm{CH}), 126.2(\mathrm{CH}), 125.9(\mathrm{CH}), 125.6(\mathrm{CH}), 124.8(\mathrm{CH}), 119.7(\mathrm{C})$, $22.1\left(\mathrm{CH}_{3}\right), 21.7\left(\mathrm{CH}_{3}\right), 13.8\left(\mathrm{CH}_{3}\right)$. UV-vis $\left(\mathrm{CH}_{2} \mathrm{Cl}_{2}\right): \lambda_{\max } 288.3 \mathrm{~nm}$. MS (+ESI) calcd. for $\mathrm{C}_{28} \mathrm{H}_{22} \mathrm{OS}_{2} \mathrm{~m} / \mathrm{z}$ $439.1185(\mathrm{M}+\mathrm{H})$, found $\mathrm{m} / \mathrm{z} 439.1197$.

\section{Acknowledgements}

This project has received funding from the European Union's Seventh Programme for research, technological development and demonstration under grant agreement No 308768. JR thanks the Engineering and Physical Sciences Research Council (EPSRC) and European Thermodynamics Ltd for support of a studentship. LB thanks Dr. David Robinson for his advice and recommendations. All authors are grateful to the EPSRC UK NSCCS Computational Service for access facilities. 


\section{References}

1. a) Chu, C. W.; Shao, Y.; Shrotriya, V.; Yang, Y.; Appl. Phys. Lett., 2005, 86, 243506; b) Jadhav, P. J.; Mohanty, A.; Sussman, J.; Lee, J.; Baldo, M. A.; Nano Lett., 2011, 11, 1495-1498; c) Tritsch, J. R.; Chan, W. L.; Wu, X.; Monahan, N. R.; Zhu, X. Y.; Nat. Commun., 2013, 4, 2679; d) Thompson, N. J.; Wilson, M. W. B.; Congreve, D. N.; Brown, P. R.; Scherer, J. M.; Bischof, T. S.; Wu, M.; Geva, N.; Welborn, M.; Van Voorhis, V.; Bulović, V.; Bawendi, M. G.; Baldo, M. A.; Nature Mater., 2014, 13, 1039; e) Wu, T. C.; Thompson, N. J.; Congreve, D. N.; Hontz, E.; Yost, S. R.; Van Voorhis, V.; Baldo, M. A.; Appl. Phys. Lett., 2014, 104, 193901; f) Shao, Y.; Sista, S.; Chu, C. W.; Sievers, D.; Yang, Y.; Appl. Phys. Lett., 2007, 90, 103501.

2. a) Casian, A.; Sanduleac, I.; J. Electron. Mater., 2014, 43, 3740-3745; b) Casian, A.; Dusciac, V.; J. Electron. Mater., 2013, 42, 2151-2156; c) Pudzs, K.; Vembris, A.; Busenbergs, J.; Rutkis, M.; Woodward, S.; Thin Solid Films 2016, 598, 214-218.

3. a) Müller, A. M.; Avlasevich, Y. S.; Schoeller, W. W.; Müllen, K.; Bardeen, C. J. Am. Chem. Soc. 2007, 129, 14240-14250; b) Yagodkin, E.; Douglas, C. J. Tetrahedron Lett. 2010, 51, 3037-3040; c) Papagni, A.; Trombini, C.; Lombardo, M.; Bergantin, S.; Chams, A.; Chiarucci, M.; Miozzo, L.; Parravicini, M. Organometallics 2011, 30, 4325-4329; d) Gu, X.; Luhman, W. H.; Yagodkin, E.; Holmes, R. J.; Douglas, C. J. Org. Lett. 2012, 14, 13901393; e) McGarry, K. A.; Xie, W.; Sutton, C.; Risko, C.; Wu, Y.; Young, Jr., V. G.; Brédas, J-L; Frisbie, C.D.; Douglas, C. J. Chem. Mater, 2013, 25, 2254-2263; f) Mamada, M.; Katagiri, H.; Sakanoue, T.; Tokito, S. Crystal Growth \& Design, 2015, 15, 442-448; g) Toshihiro Okamoto, T.; Nakahara, K.; Saeki, A.; Seki, S.; Oh J. H.; Akkerman, H. B.; Bao, Z.; Matsuo, Y. Chem. Mat. 2012, 23, 1646-1649; h) Geary, L. M.; Chen, T. Y.; Montgomery, T. P.; Krische, M. J. J. Am. Chem. Soc., 2014, 136, 5920-5922.

4. Lin, Y.-C.; Lin, C.-H. Org. Lett. 2007, 9, 2075-2078.

5. Chen, M.; Chen, Y.; Liu, Y. Chem. Commun. 2012, 48, 12189-121191.

6. Burroughs, L.; Ritchie, J.; Ngwenya, M.; Khan, D.; Lewis, W.; Woodward, S. Beilstein J. Org. Chem., 2015, 11, 273-279.

7. Albrow, V.; Biswas, K.; Crane, A.; Chaplin, N.; Easun, T.; Gladiali, S.; Lygo, B.; Woodward, S.; Tetrahedron: Asymmetry, 2003, 14, 2813-2819.

8. a) Lee, C. ; Yang, W.; Parr, R. G. Phys. Rev. B, 1988, 37, 785-789; b) Becke, A. D., Phys. Rev. A, 1988, 38, 30983100; c) Becke, A. D. J. Chem. Phys., 1993, 98, 1372; e) Becke, A. D. ; J. Chem. Phys., 1993, 98, 5648-5652; f) Stephens, P. J.; Devlin, F. J.; Chabalowski, C. F.; Frisch, M. J. J. Phys. Chem., 1994, 98, 11623-11627.

9. a) Redfern, P. C.; Zapol, P.; Curtiss, L. A.; Raghavachari, K. J. Phys. Chem. A, 2000, 104, 5850-5854; b) Check, C. E.; Gilbert, T. M. J. Org. Chem., 2005, 70, 9828-9834; c) Grimme, S. Angew. Chem. Int. Ed., 2006, 45, 44604464.

10. a) Montgomery, J. A.; Frisch, M. J.; Ochterski, J. W.; Petersson, G. A.; J. Chem. Phys., 1999, 110, 2822-2827; b) Montgomery, J. A.; Frisch, M. J.; Ochterski, J. W.; Petersson, G. A.; J. Chem. Phys., 2000, 112 6532-6542.

11. Eyring, H.; J. Chem. Phys., 1935, 3, 107-115.

12. Zhao, Y. H.; Abraham, M. H.; Zissimos, A. M.; J. Org. Chem. 2003, 68, 7368-7373.

13. Hansch, C.; Leo, A.; Taft, R. W.; Chem. Rev., 1991, 91, 165-195.

14. a) Singh, S.; Jones, W. J.; Siebrand, W.; Stoicheff, B. P.; Schneider, W. G.; J. Chem. Phys., 1965, 42, 330-342; b) Swenberg, C. E.; Stacy, W. T.; Chem. Phys. Lett., 1968, 2, 327-328; c) Geacintov, N.; Pope, M.; Vogel, F. E., III.; Phys. Rev. Lett., 1969, 22, 593-596.

15. Frisch, M. J.; Trucks, G. W.; Schlegel, H. B.; Scuseria, G. E.; Robb, M. A.; Cheeseman, J. R.; Scalmani, G.; Barone, V.; Mennucci, B.; Petersson, G. A.; Nakatsuji, H.; Caricato, M.; Li, X.; Hratchian, H. P.; Izmaylov, A. F.; Bloino, J.; Zheng, G.; Sonnenberg, J. L.; Hada, M.; Ehara, M.; Toyota, K.; Fukuda, R.; Hasegawa, J.; Ishida, M.; Nakajima, T.; Honda, Y.; Kitao, O.; Nakai, H.; Vreven, T.; Montgomery, J. A., Jr.; Peralta, J. E.; Ogliaro, F.; Bearpark, M.; Heyd, J. J.; Brothers, E.; Kudin, K. N.; Staroverov, V. N.; Kobayashi, R.; Normand, J.; Raghavachari, K.; Rendell, A.; Burant, J. C.; Iyengar, S. S.; Tomasi, J.; Cossi, M.; Rega, N.; Millam, J. M.; Klene, M.; Knox, J. E.; Cross, J. B.; Bakken, V.; Adamo, C.; Jaramillo, J.; Gomperts, R.; Stratmann, R. E.; Yazyev, O.; Austin, A. J.; Cammi, R.; Pomelli, C.; Ochterski, J. W.; Martin, R. L.; Morokuma, K.; Zakrzewski, V. G.; Voth, G. A.; Salvador, P.; Dannenberg, J. J.; Dapprich, S.; Daniels, A. D.; Farkas, Ö.; Foresman, J. B.; Ortiz, J. V.; Cioslowski, J.; Fox, D. J. Gaussian 09, Revision D.01, Gaussian, Inc., Wallingford CT, 2009.

16. Yanai, T.; Tew, D. P.; Handy, N. C.; Chem. Phys. Lett., 2004, 393, 51-57.

17. Hirata, S.; Head-Gordon, M.; Chem. Phys. Lett., 1999, 314, 291-299.

18. Zhang, G.; Musgrave, C. B.; J. Phys. Chem. A, 2007, 111, 1554-1561.

19. Dennington, R.; Keith, T.; Millam, J.; GaussView, Version 5, Semichem Inc., Shawnee Mission, KS, 2009. 